Brief Communication

Comunicação Breve

Maria Inês Rebelo Gonçalves 1,2 Carla Bogossian Remaili2

Mara Behlau ${ }^{3}$

Keywords

Deglutition disorders Speech, language and hearing sciences Eating disorders

Risk index

Deglutition

Questionnaires

Descritores

Transtornos de deglutição

Fonoaudiologia

Transtornos da alimentação

Indicador de risco

Deglutição

Questionários

Correspondence address:

Maria Inês Rebelo Gonçalves

Speech Therapy Department,

R. Botucatu, 802, Vila Clementino,

São Paulo (SP), Brazil, CEP: 04023-900.

E-mail: mariainesrg@gmail.com

Received: 05/29/2012

Accepted: 02/18/2012

\section{Cross-cultural adaptation of the Brazilian version of the Eating Assessment Tool - EAT-10}

\author{
Equivalência cultural da versão brasileira do Eating \\ Assessment Tool - EAT-10
}

\begin{abstract}
The Eating Assessment Tool (EAT-10) was conceptually developed in the United States from data collected from 482 patients, for use as a self-administered survey regarding risk identification of dysphagia and symptoms related to clinical response to treatment. The purpose of this study is to present the cultural equivalence of the Brazilian version of the EAT-10. The process followed the Scientific Advisory Committee of Medical Outcome Trust (SACMOT). The questionnaire was translated by two Brazilian bilingual speech-language pathologists, aware of the purpose of this study. A back translation was performed by a third Brazilian speech-language pathologist, bilingual and English teacher that had not participated in the previous stage. After comparing both translations, a final version of the questionnaire was produced and called Instrumento de Autoavaliação da Alimentação (EAT-10). It was administered to 107 adult inpatients of the Hospital São Paulo, cwith request for bedside clinical evaluation of swallow. During the process of translation and cultural adaptation, no item was modified and/or suppressed. The EAT-10 maintained the same structure as the original American English version with ten questions, of which three of functional domain, three of emotional domain and four of physical symptoms domain. The cultural equivalence of the Brazilian version of the EAT-10 was demonstrated, being a score of three points or above it the cutoff for dysphagia risk, also for the Brazilian population.
\end{abstract}

\section{RESUMO}

O Eating Assessment Tool (EAT-10) foi conceitualmente desenvolvido nos Estados Unidos da América, a partir de informações de 482 pacientes, para o uso como instrumento de autoavaliação do risco de disfagia e de sintomas para evidenciar respostas clínicas ao tratamento. O objetivo deste estudo é apresentar a equivalência cultural da versão brasileira do EAT-10. O processo seguiu as recomendações do Scientific Advisory Committee of Medical Outcome Trust (SACMOT). O questionário foi traduzido para a língua portuguesa por duas fonoaudiólogas brasileiras bilíngues, cientes do objetivo desta pesquisa. Uma retrotradução foi efetuada por uma terceira fonoaudióloga brasileira, bilíngue e professora de inglês, não participante da etapa anterior. Após comparação das traduções, produziu-se uma única versão traduzida denominada Instrumento de Autoavaliação da Alimentação (EAT-10), aplicada em um grupo de 107 indivíduos adultos, internados no Hospital São Paulo, com solicitação de avaliação clínica fonoaudiológica da deglutição. No processo de tradução e adaptação cultural, não houve modificação e/ou eliminação de nenhuma questão. A composição do EAT-10 reflete a versão original do inglês, com dez questões, sendo três do domínio funcional, três do domínio emocional e quatro do domínio físico. Houve equivalência cultural do EAT-10 para o português brasileiro, sendo um escore de três ou mais pontos a nota de corte para risco de disfagia também na realidade nacional.

Study was carried out at Hospital São Paulo - UNIFESP - São Paulo (SP), Brazil.

(1) Speech Language Pathology and Audiology Department, Universidade Federal de São Paulo - UNIFESP São Paulo (SP), Brazil.

(2) Speech Language Pathology and Audiology Integrated Service, Hospital São Paulo - UNIFESP - São Paulo (SP), Brazil.

(3) Centro de Estudos da Voz - CEV - São Paulo (SP), Brazil.

Conflict of interests: nothing to declare. 


\section{INTRODUCTION}

Deglutition disorders, also called dysphagia, affect most of the population. In literature, there are no accurate data concerning the prevalence of dysphagia. However, epidemiological studies indicate that it can affect as much as $22 \%$ of patients aged 50 years or more ${ }^{(1)}$. In the United States, approximately 10 million people are assessed for difficulties in deglutition every year(2).

It is important to mention that difficulties in deglutition have a negative impact on many aspects related to quality of life ${ }^{(3)}$ and may lead to significant rises in morbidity and mortality of patients ${ }^{(4)}$.

We can observe the presence of dysphagia in $20 \%$ of patients diagnosed with Parkinson's Disease ${ }^{(5)}$ and $22 \%$ with amyotrophic lateral sclerosis ${ }^{(6)}$. This percentage can increase from $25 \%$ to $70 \%$ in strokes ${ }^{(7)}$.

The quantification of the impact of dysphagia, be it on quality of life, pulmonary complications, etc., should be fast and, preferably, made with clinical screening, by screening for negative consequences of the risk of deglutition disorders.

In order to quantify such an impact, as well as to assess the evolution of the patient and make therapeutic decisions, different protocols with various objectives have been developed, such as the functional oral intake scale (FOIS) ${ }^{(8)}$, the O'Neill( ${ }^{(9)}$ scale, the dysphagia severity scale, and the Rosenbeck ${ }^{(10)}$ scale, for quantifying laryngeal penetration and/or tracheal aspiration. Most of the protocols were originally developed in English and became clinically and scientifically popular.

The Scientific Advisory Committee of Medical Outcome Trust $^{(11)}$ recommends standard criteria for the development of protocols that assess quality of life and validation of nonEnglish versions of the tool.

In order for these instruments to be used in other cultural contexts, they should be translated and adapted according to international rules and their measurement priorities should be demonstrated in specific cultural contexts ${ }^{(11)}$. Therefore, the instrument should be carefully translated and culturally adapted. It is not enough to perform a mere literal translation that may not carry with it the nuances related to different cultural and social contexts of people who are not English native speakers. At the end of the process, the translated and adapted protocol should be tested to guarantee its adaptation and validity for specific populations, languages, and cultures, according to international guidelines of language adaptation and cultural equivalence, validity, reproducibility, sensibility, and reliability ${ }^{(11)}$.

The Eating Assessment Tool (EAT-10) was conceptually developed based on the data gathered from 482 patients, and it is used as a self-assessment instrument to identify the risk of dysphagia ${ }^{(12)}$, favoring the need for a multidisciplinary intervention as early as possible. With 10 simple questions, the instrument provides information on functionality, emotional impact, and physical symptoms that a deglutition disorder can cause in a patient.

The objective of this study was to demonstrate the cultural equivalence of the Brazilian version of the EAT- $10^{(12)}$ by means of cultural and language adaptations of the instrument.

\section{METHODS}

After an approval by the Research Ethics Committee (Report Number: 159,929), the questionnaire was translated to Portuguese by two Brazilian bilingual speech-language pathologists, who were aware of the objective of this research. They performed the conceptual translation, thus avoiding the literal use of words or sentences. Afterwards, both translations were compared and compiled into one. A back-translation was also conducted by a Brazilian bilingual speech-language pathologist, who is an English teacher of and did not participate in the prior stage of the study. A comparison was made between the materials of translation, back-translation, and the content of the original instrument. Discrepancies were analyzed and discussed by a committee composed of three speech-language pathologists specialized in dysphagia, with proficiency in English, who performed the necessary changes by consensus; thus, a final protocol was produced and given the title "Instrumento de Autoavaliação da Alimentação" - EAT-10 (Appendix 1).

In order to obtain the cultural equivalence and validation of the tool, EAT-10 was tested in a group of 107 adult patients, who were inpatients at Hospital São Paulo; 30 of them were in ICU and 77 in infirmary. All participants signed the Informed Consent Form.

Inclusion criteria were as follows: hospitalized adult patients with good cognitive level, ability to read and/or understand the questionnaire, and a medical request for speechlanguage evaluation.

Exclusion criteria were as follows: patients who had difficulties with reading and/or understanding sentences and/or instructions, those lacking interest or unable to participate in the study, presence of changes that might prevent the application of the protocol, and an unstable clinical.

The discriminating power of EAT-10 was assessed by means of ROC (receiver operating curve) analysis.

\section{RESULTS}

The patients answered all the 10 questions, without asking for clarification or help. Out of the 107 participants, only 13 had their questions read by the researcher since they expressed difficulties with reading or did not have reading glasses at the time of examination.

In the process of translation and cultural adaptation, there was no change and/or elimination of any question. The final format of the translated EAT-10 (Appendix 1), after cultural and language adaptation, presents 10 questions, out of which three refer to functional domain; for example, "Swallowing liquids takes extra effort"; three refer to the emotional domain (psychological effect); for instance, "The pleasure of eating is affected by my swallowing"; and four refer to the physical domain (organic symptoms); for instance, "My swallowing problem has caused me to lose weight."

In order to verify the ability to distinguish persons without dysphagia, or mild dysphagia, from those with more severe deglutition problems, by using the sum of EAT results, an ROC curve was established and revealed that the instrument 
has discriminative power of 0.7297 or $72.97 \%$ ( $\mathrm{p}=0.0029)$. The cutoff point was 3 , with $69.70 \%$ sensitivity and $72.00 \%$ specificity, defined as the separation limit between pass and fail in the feeding screening, with good accuracy (Graphic 1).

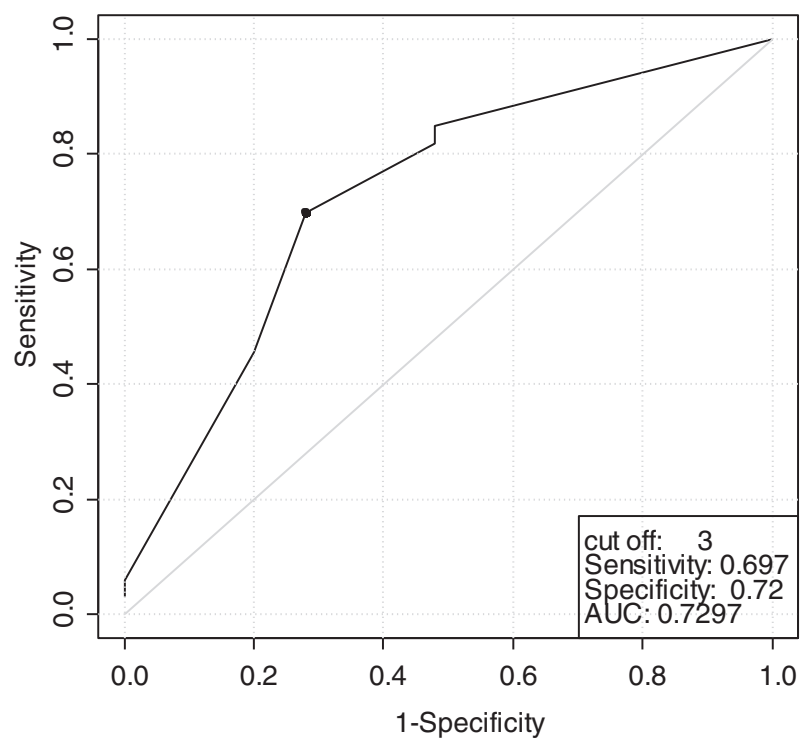

Caption: $\mathrm{AUC}=$ area under the receiver operating curve.

Graphic 1. Receiver operating Characteristic curve to discriminate dysphagia.

Thus, the 3-point score was the cutoff score for the risk of dysphagia in the original version as well; that is, the translation of the instrument to Portuguese did not interfere in the cutoff score.

\section{DISCUSSION}

Obtaining cultural equivalence is an essential first step in the process of validating protocols ${ }^{(4)}$ because only after this step the whole process of validation takes a decisive shape. Therefore, a translated questionnaire can be administered to a target population by means of cultural adaptation.

Literature is very clear as to the need for specificity in a protocol that identifies the risk of dysphagia, that is, how specific it is for the situation or pathology of a population for which it is used. EAT-10 is an important contribution for the identification of the risk and symptoms of dysphagia and can help with early identification of the need for multidisciplinary intervention and clinical follow-up. Therefore, a 3-point score in the questionnaire already points to the risk of dysphagia, and the patient should be referred to speech-language evaluation of deglutition.

It is important to mention that EAT-10 can be applied to all patients suspected for dysphagia, since they present with conditions pointing to the presence of the disorder. It is a simple and fast questionnaire that does not require visual analog measurements or formulas for calculation. In addition, it can be used by several health professionals, facilitating an increased number of indications for speech-language evaluations, and thus, making significant contributions such as identifying the need for earlier interventions, reduced costs of treatments, and improved quality of life.

The process of validating EAT-10 in Brazilian Portuguese is already being concluded and will enable its reliable use in clinical practice and research, given that the various steps used in the protocol helps to understand the common characteristics of patients with dysphagia. Future analyses will be able to compare these results after using a standard instrument validated to our language, which will lead to enhanced accuracy of findings in future research.

\section{CONCLUSION}

The cultural equivalence of EAT-10 to Brazilian Portuguese was observed and it was found there was no need to change or remove any question contained in the original protocol.

\section{ACKNOWLEDGEMENTS}

We would like to express our thanks to the team of Nestlé Health Science for the support.

*MIRG was responsible for supervising data collection and formatting, as well as preparation of the manuscript; CBR collaborated with data collection and formatting and assisted with the preparation of the manuscript; MB was in charge of the general orientation concerning the cultural adaptation and collaborated with the preparation of the manuscript.

\section{REFERENCES}

1. Howden CW. Management of acid-related disorders in patients with dysphagia. Am J Med. 2004;117(5A):44S-48S

2. Domench E, Kelly J. Swallowing disorders. Med Clin North Am. 1999;83(1):97-113.

3. Lovell SJ, Wong HB, Loh KS, Ngo RY, Wilson JA. Impact of dysphagia on quality of life in nasopharyngeal carcinoma. Head Neck. 2005;27(10):864-72.

4. Palmer JB, Drennan JC, Baba M. Evaluation and treatment of swallowing impairments. Am Fam Physician. 2000;61(8):2453-62.

5. Volonté MA, Porta M, Comi G. Clinical assessment of dysphagia in early phases of Parkinson's disease. Neurol Sci. 2002;23(Suppl 2):S121-2.

6. Kidney D, Alexander M, Corr B, O’Toole O, Hardman O. Oropharyngeal dysphagia in amyotrophic lateral sclerosis: neurological and dysphagia specific rating scales. Amyotroph Lateral Scler Other Motor Neuron Disord. 2004;5(3):150-3.

7. Mann G, Hankey GJ, Cameron D. Swallowing disorders following acute stroke: prevalence and diagnostic accuracy. Cerebrovasc Dis. 2000;10(5):380-6.

8. Crary MA, Mann GDC, Groher ME. Initial psychometric assessment of a functional oral intake scale for dysphagia in stroke patients. Arch Phys Med Rehabil. 2005;86(8):1516-20.

9. O'Neil KH, Purdy M, Falk J, Gallo L. The dysphagia outcome and severity scale. Dysphagia.1999;14(3):139-45.

10. Rosenbek JC, Robbins J, Roecker EB, Coyle JL, Wood JL. A penetration-aspiration scale. Dysphagia. 1996;11(2):93-8.

11. Scientific Advisory Committee of Medical Outcomes Trust. Assessing health status and quality of life instruments: attributes and review criteria. Qual Life Res. 2002;11(3):193-205.

12. Belafsky PC, Mouadeb DA, Rees CJ, Pryor JC, Postma GN, Leonard RJ, et al. Validity and reliability of the Eating Assessment Tool (EAT-10). Ann Otol Rhinol Laryngol. 2008;117(2):919-24. 
Appendix 1. Instrument to identify the risk of dysphagia

Instrumento de Autoavaliação da Alimentação (EAT-10)

Data:

Prontuário:

Nome:

Peso:

Altura:

Fale sobre seu problema de engolir.

Liste todos os exames de deglutição que você fez (data e resultados).

O quanto essas situações são um problema para você?

Marque o melhor número para o seu caso.

1. Meu problema para engolir me faz perder peso.

2. Meu problema para engolir não me deixa comer fora de casa.

3. Preciso fazer força para beber líquidos.

4. Preciso fazer força para engolir comida (sólidos).

5. Preciso fazer força para engolir remédios.

6. Dói para engolir.

7. Meu problema para engolir me tira o prazer de comer.

8. Fico com comida presa/entalada na garganta.

9. Eu tusso quando como.

10. Engolir me deixa estressado.

0 = não é um problema 4 = é um problema muito grande

$\begin{array}{lll}0 & 1 & \\ 0 & 1 & \\ 0 & 1 & \\ 0 & 1 & \\ 0 & 1 & \\ 0 & 1 & \\ 0 & 1 & \\ 0 & 1 & \\ 0 & 1 & \\ 0 & 1\end{array}$

$\begin{array}{lll}2 & 3 & 4 \\ 2 & 3 & 4 \\ 2 & 3 & 4 \\ 2 & 3 & 4 \\ 2 & 3 & 4 \\ 2 & 3 & 4 \\ 2 & 3 & 4 \\ 2 & 3 & 4 \\ 2 & 3 & 4 \\ 2 & 3 & 4 \\ \text { EAT-10 } & & \end{array}$

